\title{
Comic Strips and Grammar Development among Iranian Teenage EFL Learners
}

\section{Niloufar Koleini ${ }^{1}$ \& Mahmood Hashemian ${ }^{2 *}$}

\section{* Correspondence: \\ hashemian-m@sku.ac.ir \\ 1. Islamic Azad University, Najafabad Branch, Iran \\ 2. Department of English Language, Faculty of Letters \& Humanities, Shahrekord University, Iran}

Received: 10 April 2021

Revision: 6 July 2021

Accepted: 18 November 2021

Published online: 20 December 2021

\begin{abstract}
This study was an attempt to examine the effect of using comic strips on improving grammar recognition and performance among Iranian young EFL learners. To this end, one experimental and one control groups were formed, each having 45 preintermediate participants chosen via convenience sampling. The researcher-made pretests of grammar and speaking assured the researchers that the participants did not know the grammatical points targeted in this study. In continuation, the experimental group received grammar instruction with the aid of comic strips, and the control group was taught the same grammar points through conventional methods of grammar teaching. After 16 sessions, both groups sat for a researcher-made grammar posttest and speaking test. Also, an interview was conducted to evaluate the extent to which the treatment for the experimental group and conventional instruction for the control group were effective. Data collected from the groups were, then, submitted for data analysis including ANOVA and $t$ test. Results indicated that the implementation of comic strips could have a positive effect on grammatical competence and performance.
\end{abstract}

Keywords: comic strips, grammar recognition, grammar instruction, language teaching 


\section{Introduction}

Among all the components of English teaching career, grammar is the foundation and plays a vital role in English teaching. As Rinvolucri and Davis (1995, p.10) have stated, "teaching the grammar of English is not simply a question of handing our clear, linguistic information to the learners; rather, the success lies in using it with perfection in oral and written daily communications." Without the knowledge and application of grammar, no teacher can be effective. In fact, grammar constitutes a critical part of any language and is a device for constructing and expressing meaning, without which effective communication would be impossible (Crivos \& Luchini, 2012).

From second language (L2) learners' perspective, the significance of grammar has been acknowledged and grammar is important. In fact, many L2 students believe that knowledge of grammar is necessary for their ability to learn a new language (Abbasian-Boroujeni, 2012). These students, when responding to a needs analysis, usually state, "I want to study grammar. If I know grammar very well, I'll be able to speak well and get a good job." Those who have studied English in their own countries often equate language learning with learning grammar. And, those who have acquired English imperfectly in this country through interactions with native speakers also acknowledge the significance of grammar, as they may have faced misunderstandings because of their grammatical deficiencies. Despite such empirical support (Abbasian-Boroujeni, 2012; Crivos \& Luchini, 2012) for learning and teaching grammar over the previous decades, the question of how to enhance grammar instruction has been contentious. Indeed, there seems to be a dire need of devising newer ways to teach grammar more effectively.

The other point to be made here is that, as Persha and Nawvi (2004) have mentioned, vision is the most remarkable sensory system for humans. Indeed, eyesight has a significant role in all areas of development, especially in the cognitive area, where learning a second or foreign language highly depends on. Considering this, devising teaching techniques in which L2 learners' vision is actively engaged can boost their understanding, as the instruction is being delivered through their most receptive sensory channel. Recently, a number of researchers (Arast \& Gorjian, 2016; Chaikovska, 2018; Kusumawati \& Khairuddin, 2017) have discussed the benefits of presenting information using visual components, such as comic strips, visual text, spoken text, graphics, and videos on language learning.

In another study by Sun and Dong (2004), the information presented in cartoons, spoken words, graphics, and video formats can be integrated to create an authentic, attractive, and multisensory language context for English as a Foreign Language (EFL) learners. In the same line, Kost, Foss, and Lenzini (1999) found that their EFL learners performed better on both production and recognition vocabulary tests when they were allowed to use a combination of visual text and graphics. Considering this, designing pedagogically effective multimedia instruction in L2 learning has been an important consideration (Hoven, 1999; Liu, Moore, Graham, \& Lee, 2002). Mayer and Moreno (2002, p.44) focused on the cognitive theory of visual learning. They further mentioned that "verbal stimuli and visual stimuli detected by our sensory systems are processed in different systems of the brain (verbal system and visual system), mixing of which can multiply the amount and depth of learning."

Considering all the above, which can be summarized as (1) the importance of grammar and (2) the importance of vision, a large number of educators (Akkaya, 2013; Chaikovska, 2018; Kilickaya \& Krajka, 2012; McVicker, 2007) have regarded comic strips as one of the most innovative educational materials to be applied in teaching grammar. According to the Oxford English Dictionary, comics are defined as an art form that features a series of static images in a fixed sequence, usually to tell a story. Also Hayman, Greg, and Pratt (2005, p.418) define comics as "a series of some pictures that include a story, which are either alone or with a short text." Comics are typically drawn on paper and are normally accompanied by a piece of short text. The most commonly seen types of comics are newspaper strips, magazine strips, and even comic books. Darvell (1997, p.203) mentioned that "we never forget our childhood tales or movies that we watched many years ago." This indicates the effectiveness of using such visual applications in transferring knowledge to children. In fact, such long-term learning should have some implications for education.

Comic strips are neither writings nor pictures. It is a synthesis text or picture which reaches in relation to another factor which is used as complementary (Akkaya, 2013). That is to say, comic strips are narrative style and an art of fiction formed by the amalgamation of two main elements, that is, text and picture. In terms of the most distinctive characteristics of comic strips which is the integration of drawing and writing, it can be thought that texts formed by comic strips can be more interesting to readers. Actually, comic strips are a very powerful teaching method because they make learning contextualized and, consequently, meaningful (Hadzigeorgiou \& Stefanich, 2000). 


\subsection{Statement of the Problem}

This study was intended to fill a number of gaps. As just discussed above, grammar is often seen as "critically important in the path of learning a foreign language" (Lin, 2010, p.13). Along the same lines, effective L2 grammar learning is particularly important for EFL learners, as they have less exposure to the English language in their daily life. Still, many Iranian EFL learners frequently suffer from poor grammatical competence (recognition) and performance (production), despite years of English study. In fact, one of the many-heard complaints among Iranian English learners is that they feel desperate in developing reliable grammar skills. Considering this, it can be suggested that one of the major concerns among most Iranian teachers and researchers is how to efficiently improve their learners' grammatical competence.

The other goal of this study was applying grammar in appropriate contexts. The question of how grammar can be taught efficiently in a way that engages the L2 learner and promotes communicative skills (production skills) needs to be addressed. Indeed, the question of what types of input the L2 teacher can deliver in the class so as to enable students to use grammatical structures in their appropriate context has remained widely unanswered (Wu, 2007). In this regard, this study capitalized on the model proposed by van Patten and Lee (2003), which is a process-based instruction and emphasizes the importance of presenting grammatical structures in a way to ensure that it becomes part of the intake.

Likewise, in Iran's EFL context, how effectively the EFL learners can use the grammatical structures has been among the primary concerns of Iranian English teachers (Abbasian-Boroujeni, 2012). It is often heard that many Iranian EFL learners complain about the wrong use of grammatical structures they have learned before, which might be attributed to the ineffectiveness of instruction. That is why devising some novel ways to help English learners gain deeper skills in grammar is highly essential. Among all the ways, using comic strips can be research-worthy.

Furthermore, another important issue in L2 education is that traditional instructional approaches, sometimes, cause a negative impression of L2 learning. According to Turkmen (2008), many L2 students think that learning an L2 is a boring action carried out in language schools. This attitude can create a sense of reluctance about L2 learning and it probably causes failure of some L2 students. As such, Iranian EFL students cannot be secure from this problem. Considering this, the present study was an attempt to offer the use of instructional comics which emphasize the entertaining side of L2 learning. Hence, the results of this study can fill the gap currently existing between many L2 students and English classrooms, especially when it comes to grammar instruction.

\subsection{Research Questions}

Based on what is discussed so far, the present study sought answers for the following questions:

1. Do comic strips have any significant effect on Iranian EFL learners' recognition of the grammatical structures of prepositions?

2. Do comic strips have any significant effect on Iranian EFL learners' performance of the grammatical structures of prepositions?

\subsection{Research Hypotheses}

In line with the questions of the study, the following two hypotheses were formed:

- $\mathrm{H}_{01}$ : Comic strips do not have any significant effect on Iranian EFL learners' recognition of the grammatical structures of prepositions.

- $\mathrm{H}_{02}$ : Comic strips do not have any significant effect on Iranian EFL learners' performance of the grammatical structures of prepositions.

\section{Literature Review}

Quite a number of studies (Arast \& Gorjian, 2016; Foulsham, Wybrow, \& Cohn, 2016; Megawati \& Anugerahwati, 2012; Merc \& Kampusu, 2013) have been conducted to examine the effect of comic strips on different fields of education. However, almost no tangible study, to the best of the present researchers' knowledge, has been dedicated to the investigation of the possible effect of comic strips on grammar learning. 
The first study to be reported here is the one carried out by Chaikovska (2018) in which he examined the effect of comic strips on reading, writing, and speaking of Ukrainian English as a Second Language (ESL) learners. The findings of the quantitative analysis indicated that the performance of all the students with comic strip effects was better than the ones without comic strips. The researcher claimed that L2 students are good at speaking, reading, and writing when the tasks are accompanied with visuals.

Regarding studies on comic strips, Bringelson (2010) listed the characteristics of comic strips that make them an ideal medium for English courses. In this study, the researcher analyzed the comprehensibility of comic strips for English teachers and students. The claim, then, was that comic strips can be efficiently applied to improve reading skills in L2 classrooms.

Williams (1995) explored how comic strips can be utilized as instructional materials for L2 students with a low-level English proficiency. The researcher found that using comic strips in L2 classrooms can guide the students to hypothesize about the language of the comics and to boost their awareness.

Another study was conducted by Liu (2004) in which he examined the effects of comic strips on increasing L2 reading comprehension among L2 learners. One-hundred and seven L2 students were divided into two groups: a low-proficiency group and a high-proficiency group. Both groups received a text with a high-proficiency level. The intriguing results of the study revealed that the low-proficiency students taking the high-level text with the comic strips scored significantly higher than the low-level students taking the high-level text only. Still, providing a comic strip with the high-level text did not enhance the high-level students' comprehension.

Still, in another study, Nassaji (2003) reviewed the role of higher-level syntactic and semantic processes and lowerlevel word recognition and processes in adult L2 reading comprehension. This study was especially intended to analyze the extent to which these processes could discriminate skilled from less-skilled readers in a sample of relatively advanced L2 readers. Sixty adult L2 learners in Canada (30 in the skilled group and 30 in the less-skilled group) were the participants. A reading task from the Reading section of the Nelson-Denny Reading Test was used as the research instrument. Word recognition, phonological processing skills, and syntactic processing skills were calculated by the task. The analysis of the data showed that all the four processes (word recognition, phonological processing skills, orthographic processing skills, and syntactic processing skills) were contributing significantly to the difference between the skilled and less-skilled L2 readers.

Rota and Izquierdo (2003) analyzed the impact of applying comics in teaching biotechnology concepts. They decided to teach biotechnology concepts via the exciting travels of three comic characters, including a scientist, a girl, and a dog. After conducting their study, they noted that the course was incredibly effective. They finally added that comics are very effective instructional instruments. Moreover, they asserted that reading comics is a remarkably active process of learning, which is ascribed to the fact that the L2 learner gets engaged in critical thinking.

Wolschke-Bulmahn and Groning (1994) pointed out that comics can significantly draw in L2 learners' attention to environmental issues. They further discussed how comics in magazines and newspapers could be extracted to teach environmental matters to the children. They finally came to the conclusion that children can be best educated about nature with a sense of humor.

And finally, Kabapinar (2005) explored the effect of comics in science teaching and learning. The researcher focused on the misconceptions which were common among the students. The findings indicated that comic strips are efficient in eliminating students' misunderstandings in science. However, the researcher warned that the success of comics is not related to simply using them, but also classroom discussions should be integrated as an additional activity.

\section{Methodology}

\subsection{Design of the Study}

As there was no true randomization in this study, it was quasi-experimental in nature. It should be noted that, although the participants were randomly selected, the population from which the sampling was done was limited to Sokhansarayan Language Institute, meaning the sampling method was convenience sampling in nature. Additionally, the independent variables in this study were the employment of comic strips. And, the dependent variables were grammar competence (recognition) as well as grammar performance (production), which were gauged through administering the grammar pretest and posttest. The control variable also was gender because all the participants were females. 


\subsection{Participants}

The participants were 90 preintermediate EFL learners within the age range of 12 to 14 who were homogenized through administering the Key English Test (KET) exam, as the proficiency test because this test is designed mainly for teenage learners of English. All of the participants were from Sokhansarayan Language Institute, as one of the most widely recognized language schools in Isfahan, Iran and as the one actively engaged in teenage courses. To neutralize gender effect, which was not among the variables of this study, all the participants were females. Furthermore, the reason why only children were targeted was that, because comic strips are by nature childlike and suit lower ages, they would not be highly welcomed by adults, indicating that the whole study could be questioned if done with adults.

As mentioned above, two groups were the participants in this study: The first one received grammar instruction through applying comic strips and was called the experimental group. The second group received grammar instruction in traditional ways and was called the control group. Moreover, in order to ensure the representativeness of the sample, the participants were randomly assigned to the two experimental and control groups. The participants' L1 was Persian. Table 1 provides descriptive statistics of the participants.

Table 1. Descriptive statistics of participants

\begin{tabular}{lllll}
\hline Groups & $n$ & Gender & Proficiency Level & Age \\
\hline Experimental & 45 & Female & Preintermediate & $12-14$ \\
\hline Control & 45 & Female & Preintermediate & $12-14$ \\
\hline
\end{tabular}

\subsection{Instruments}

This study comprised of four main instruments: The first one was a series of the KET test as the proficiency test to homogenize the participants. Produced by Cambridge University, this test has been widely used and already tried and trusted. KET is offered in two variations: KET for adult learners and KET for schools, which is for school-aged learners. Both versions of the exam lead to the same qualification. Both versions have the same exam format (they both use three exam papers). The only difference is that the topics in the version for schools have been targeted at the interests and experiences of school-aged learners. Therefore, as the participants of this study were teenagers, the latter version was chosen and employed. Considering the content of this test, it should be mentioned that it consists of three papers: paper 1 (reading and writing), paper 2 (listening), and paper 3 (speaking). Each paper has its own assigned time, which was strictly observed by the researchers to secure validity. Regarding the fact that KET measures all the four main skills in English, it can be legitimately argued that it was a perfect choice for homogenization purposes.

The second instrument was three sets of grammatical structures accompanied by some comic strips but only for the experimental group, meaning the control one received these structures without comic strips. These grammatical structures are as follows:

1. Present continuous (-ing)

2. Future (will)

3. Prepositions of location (under, in, next to, behind, etc.)

These grammatical structures come from the book Family and Friend, taught at Sokhansarayan Language Institute where this study was hosted, as the main course book. Also, to ensure validity, the grammatical structures were checked and commented by some English Language Teaching (ELT) professionals. They argued that, because these structures are widely used in English learning, they were quite worth being chosen. 
The third instrument was a grammar test which was made designed based on the structures mentioned above. This test was researcher-made; thus, it was checked for the indexes of validity and reliability prior to its main administration. The purpose of this test was to check the participants' grammatical competence (recognition) before and after receiving the treatment in the experimental group and conventional instruction in the control group. As with the content validity of the test, because this test measures grammatical competence which was the intended construct in this study, it can be argued that it had content validity.

Moreover, the test was shown to two ELT professionals and they provided their comments on it. Except for some minor modifications, no serious change was requested by them. This could also add to the validity of the test. With regard to the reliability of the grammar test, it was distributed among 15 Iranian EFL learners who were learning English in Sokhansarayan, but they were not among the 90 learners as the main participants. However, all of the criteria considered for the main participants were also considered for the pilot-phase students. Having amassed the data from those 15 learners, Cronbach's alpha was applied and the reliability of the test was calculated to be 7.1, indicating a high rate of reliability. As Hatch and Lazaraton (1991, p.215) have argued, a strong reliability coefficient "ranges from about 0.65 to 0.95 ." Table 2 is a description of the pilot test:

Table 2. Pilot test description

\begin{tabular}{clll}
\hline No. of Items & No of Participants & Cronbach's Alpha & Excluded Items \\
\hline 42 & 15 & .71 & 0 \\
\hline
\end{tabular}

The last point to be mentioned about the above instrument is that it was administered two times: The first time was at the beginning of the course or before the treatment to make sure that the students did not considerably know how the grammatical structures were chosen for the study. The second time was after the treatment to evaluate the effectiveness of the teaching grammar with comic strips. However, in order to avoid the test practice effect (Bachman, 1990), we applied some modifications in the content of the questions, leaving the main construct of the test intact. For example, there was a test in the pretest which read:

A: Hello Jack. When will you give my money back?

B: Hello Fred. I ................. (pay) you next month.

The above test was changed into the following on the posttest (see sample items in Appendixes A and B):

A: Hi. When do you think you will finish your project?

B: Hello teacher. I.

(do) it next week.

And, the last instrument was an interview which was conducted to evaluate the extent to which the treatment (for the experimental group) and conventional instruction (for the control group) was effective. The questions asked during the interview sessions were in a way requiring the participants to use the grammatical structures in the contexts given to them. Furthermore, to ensure the objectivity of the scorings, each interview was attended by two raters who were already briefed about the premises and purposes of the study. In this way, more reliable results were obtained. However, an interrater reliability was also calculated to further avoid any subjective assessment, the results of which are provided in Table 3. Moreover, with regard to the validity of the interview, the questions asked during the interview were checked by two Iranian Teaching English as a Foreign Language (TEFL) professors and received some modifications to assure content validity.

Table 3. Description of interrater reliability for interview questions

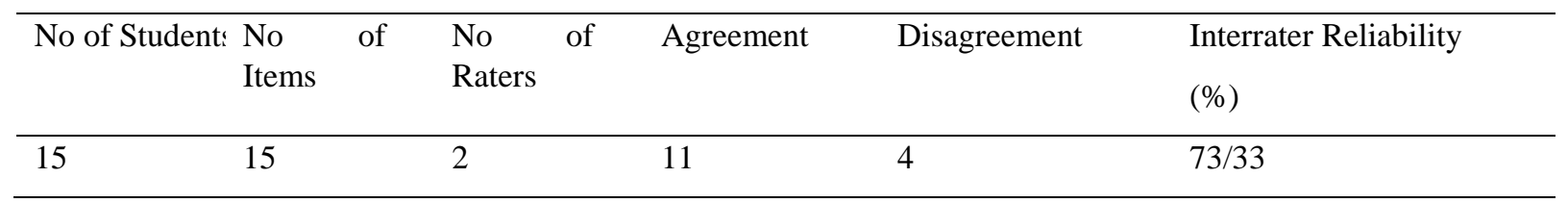


A word of caution, however, should be made here. The interviewers were asked to focus primarily on the participants' grammatical performance, as it was the main concern of this study. Indeed, they were required to evaluate the participants' ability to properly use the taught structures during the speaking stream. However, to further assure the objectivity of the raters, they were asked to score the interviewees out of 20 , which was chosen as the rating scale. The final score of each interviewee was obtained through totaling and, then, averaging the two scores given by each interviewer. With regard to the content of the interview, some speaking questions were extracted from the book Family and Friends taught at Sokhansarayan Institute. This book, which is the course book of many English institutes in Iran, includes a great collection of grammar lessons. Moreover, to establish the content validity of the interview questions, they were reviewed by two TEFL professionals to tune its content. The list of the questions asked during the interview is presented in Appendix C.

\subsection{Data Collection Procedure}

As the first step to start this study, as many as 90 teenage EFL learners from Sokhansarayan Language Institute were randomly chosen. Having been homogenized through KET as the proficiency test, the participants were randomly divided into two groups of experimental and control. Then, a piloted grammar pretest was conducted to make sure that the participants did not considerably know how to use the intended structures. Here, if a participant knew how to use the structures in more than $3 \%$ of the pretest questions, she was excluded from the list. Less than this could be attributed to chance factor because the test format in some of the questions was multiple-choice and this format is open to chance factor (Moore \& McCabe, 2006).

The next step was the introduction of the treatment. The experimental group received grammar instruction accompanied by the comic strips. This treatment took around 16 sessions because, in Iranian English institutes, a typical semester lasts this much. However, not all the sessions were devoted to teaching the structures; rather, some practices as well as teaching other skills like listening were performed. In fact, each structure purely took only 1 session of instruction. During the teaching, each structure was presented and elaborated on based on the illustrations on the comic strips. Here, much care was practiced to choose those comics which were expressive enough as well as easy to understand. In addition, the teacher explained the context in which a structure should be used, which is technically called grammatical performance (production).

The control group received grammar instruction without applying comic strips. Here, repetition and drilling exercises, as two prevalent techniques, were used. The participants were asked to repeat and transform the structures in new situations. The duration lasted 16 sessions. Here again, the instructions were not consecutive; rather, some practice sessions existed between each main session of instruction.

As the next step, the participants sat for a piloted grammar posttest in which they answered some questions which were different in content from the ones on the pretest but tested the same grammatical structures. This was simply because of avoiding practice effect, as mentioned by Bachman (1990). The goal here was examining how far their grammatical competence (recognition) had improved due to the treatment. In continuation, the participants took part in a speaking interview in which their grammatical performance (production) was gauged. The questions of the interview were designed in a way which required the respondents apply the structures taught during the treatment.

As mentioned before, the interview sessions were attended by two raters in order to assure the reliability of the scorings. Considering this, calculating an interrater reliability was necessary and, thus, done. Having collected all the data related to the grammar pretest and posttest along with those of the interview, we could analyze and compare the results to see if the treatment, which was applying the comic strips, had any significant effect on the participants' grammatical development - both in competence (recognition) and performance (production).

\subsection{Data Analysis}

In order to seek statistically supported answers to the research questions, the results of the two groups were calculated. More specifically, in order to investigate to what extent, the comic strips would improve the participants' grammatical performance and competence after the treatment, three sets of data were collected including:

1. Grammar pretest

2. Grammar posttest 


\section{Interview}

In line with the purposes of the study, the data were analyzed descriptively and quantitatively. First of all, the descriptive statistics were used to show the numerical values such as the mean score and the standard deviation in each group. In the quantitative analyses, the statistics were computed through the statistical software SPSS (version 21). Here, a Pearson product-moment correlation, which is used to examine the extent of the correlation between two tests, was conducted. Another computation was an independent samples $t$ test which is used to compare the mean differences between two independent groups. Still, another calculation was a paired samples $t$ test, which is used to compare the before- and after-differences for the same group.

\section{Results}

\subsection{Pilot Study}

The grammar knowledge test was piloted on a group of L2 learners in order to check its reliability. As shown in Table 4, the $K R-21$ reliability index for the piloted grammar knowledge test was .81 .

Table 4. Descriptive statistics: Piloted grammar knowledge test

\begin{tabular}{llllllll}
\hline & & No & Minimum & Maximum & Mean & Std. Deviation & Variance \\
\hline Pilot & & 15 & 12 & 40 & 27.53 & 7.745 & 59.981 \\
$K R-21$ & .81 & & & & & & \\
\hline
\end{tabular}

As reported in Table 4, the reliability of the test was calculated to be .81 , indicating a high rate of reliability. As Hatch and Lazaraton (1991, p.215) have argued, a strong reliability coefficient "ranges from about 0.65 to 0.95 ."

\subsection{Main Study}

A number of statistical analyses including Pearson correlation, ANCOVA, and independent samples $t$ test were run to probe the data collected in this study. Because all these statistical techniques assume normality of the data, the ratios of skewness and kurtosis over their respective standard errors were computed. As shown in Table 5, the absolute values of these ratios were lower than 1.96. Thus, it can be concluded that the present data met the normality assumption.

Table 5. Descriptive statistics: Testing normality assumption

\begin{tabular}{|c|c|c|c|c|c|c|c|c|}
\hline \multirow[b]{2}{*}{ Group } & & \multirow{2}{*}{$\begin{array}{l}N \\
\text { Statisti } \\
\mathrm{c}\end{array}$} & \multicolumn{2}{|l|}{ Skewness } & \multicolumn{3}{|c|}{ Kurtosis } & \multirow[b]{2}{*}{ Ratio } \\
\hline & & & Statistic & $\begin{array}{l}\text { Std. } \\
\text { Error }\end{array}$ & Ratio & Statistic & $\begin{array}{l}\text { Std. } \\
\text { Error }\end{array}$ & \\
\hline \multirow{3}{*}{$\begin{array}{l}\text { Experiment } \\
\text { al }\end{array}$} & $\begin{array}{l}\text { Pregra } \\
\mathrm{m}\end{array}$ & 45 & .502 & .354 & & .763 & .695 & \\
\hline & Postgram & 45 & -.615 & .354 & & .319 & .695 & \\
\hline & $\begin{array}{l}\text { Speakin } \\
\mathrm{g}\end{array}$ & 45 & -.120 & .354 & & -.494 & .695 & \\
\hline \multirow{3}{*}{ Control } & Pregram & 45 & .434 & .354 & & -.878 & .695 & \\
\hline & $\begin{array}{l}\text { Postgra } \\
\mathrm{m}\end{array}$ & 45 & .405 & .354 & & -.118 & .695 & \\
\hline & $\begin{array}{l}\text { Speakin } \\
\mathrm{g}\end{array}$ & 45 & -.206 & .354 & & .761 & .695 & \\
\hline
\end{tabular}




\subsection{Interrater Reliability of the Speaking Test}

The participants' performance on the production of grammatical structures was rated by two raters. Pearson correlation was run to probe the interrater reliability of the speaking data. As displayed in Table 6, there was a significant agreement between the two raters, $r(88)=.906$, representing a large effect size, $p=.000$.

Table 6. Pearson correlation: Interrater reliability of speaking test

\begin{tabular}{lll}
\hline & & Second Rater \\
\hline \multirow{2}{*}{ First } & Pearson Correlation & $.906^{\text {*** }}$ \\
Rater & Sig. (2-tailed) & .000 \\
& $N$ & 90 \\
\hline
\end{tabular}

${ }^{* * *}$ Correlation is significant at the 0.01 level (2-tailed).

\subsection{KR-21 Reliability Indices of Knowledge of Grammatical Structures}

The $K R-21$ reliability indices were computed for the pretest and posttest of knowledge on grammatical structures. As shown in Table 7, the $K R-21$ reliability indices for the pretest and posttest were .19 and .85 , respectively. The low reliability index on the pretest may be justified by the fact that the participants had a homogenous distribution on the pretest. The variances for the pretest and posttest were 3.45 and 7.07, respectively. That is to say, the administration of the comic strips created variation among the participants.

Table 7. KR-21 reliability indices of pretest and posttest of grammatical structure

\begin{tabular}{llllllll}
\hline & No. & Minimum & Maximum & Mean & Std. Deviation & Variance & $K R-21$ \\
\hline Pretest & 90 & 9 & 25 & 15.64 & 3.452 & 11.917 & .19 \\
Posttest & 90 & 15 & 42 & 29.92 & 7.078 & 50.095 & .85 \\
\hline
\end{tabular}

A one-way ANCOVA was run to test the first null hypothesis, which stated that comic strips have no significant effect on Iranian EFL learners' ability to use prepositions, simple future, and present continuous in writing sentences. The analysis compared the experimental and control groups' means on the posttest of knowledge of grammatical structures after controlling for the effect of the participants' entry knowledge, as measured through the pretest. Besides the assumptions of normality shown in Table 5, ANCOVA has three more assumptions: First, ANCOVA assumes that the relationship between the dependent variable (posttest of knowledge of grammatical structures) and covariate (pretest) be a linear one. Based on the results displayed in Table $8, F(1,74)=44.43, p=.000$, it can be claimed that the statistical null hypothesis as the relationship between the two variables was not a linear one was rejected. In other words, there was a linear relationship between the dependent variable and the covariate. 
Table 8. Testing linearity assumption: Posttest knowledge of grammatical structures by groups on pretest

\begin{tabular}{|c|c|c|c|c|c|c|c|c|}
\hline & & & & $\begin{array}{l}\text { Sum of } \\
\text { Squares }\end{array}$ & $d f$ & $\begin{array}{l}\text { Mean } \\
\text { Square }\end{array}$ & $F$ & Sig. \\
\hline \multirow{5}{*}{ Posttest* Pretest } & \multirow{3}{*}{$\begin{array}{l}\text { Between } \\
\text { Groups }\end{array}$} & \multicolumn{2}{|c|}{ (Combined) } & 2373.033 & 15 & 158.202 & 5.614 & .000 \\
\hline & & \multicolumn{2}{|l|}{ Linearity } & 1252.361 & 1 & $\begin{array}{l}1252.36 \\
1\end{array}$ & $\begin{array}{l}44.43 \\
9\end{array}$ & .000 \\
\hline & & \multicolumn{2}{|l|}{$\begin{array}{l}\text { Deviation } \\
\text { Linearity }\end{array}$} & 1120.672 & 14 & 80.048 & 2.840 & .002 \\
\hline & \multicolumn{3}{|c|}{ Within Groups } & 2085.423 & 74 & 28.181 & & \\
\hline & \multicolumn{3}{|l|}{ Total } & 4458.456 & 89 & & & \\
\hline
\end{tabular}

Second, ANCOVA assumes that the linear relationship between the dependent variable and the covariate be the same across the groups, that is, homogeneity of regression slopes. The nonsignificant interaction between the covariate and the independent variable (types of treatment), $F(1,86)=2.30, p=.133$, partial $\eta 2=.026$ representing a weak effect size, indicated that the assumption of homogeneity of regression slopes was met (Table 9).

Table 9. Tests of between-subjects effects: Posttest knowledge of grammatical structures by groups on pretest

\begin{tabular}{lllllll}
\hline Source & $\begin{array}{l}\text { Type III Sum } \\
\text { of Squares }\end{array}$ & $d f$ & Mean Square & $F$ & Sig. & $\begin{array}{c}\text { Partial } \\
\text { Squared }\end{array}$ \\
\hline Group & 179.910 & 1 & 179.910 & 101.634 & .000 & .542 \\
Pretest & 1864.941 & 1 & 1864.941 & 1053.540 & .000 & .925 \\
Group * Pretest & 4.082 & 1 & 4.082 & 2.306 & .133 & .026 \\
Error & 152.234 & 86 & 1.770 & & & \\
Total & 85039.000 & 90 & & & & \\
\hline
\end{tabular}

And finally, ANCOVA assumes that there are no significant differences between the variances of the groups on the posttest, that is, the homogeneity of variance. The nonsignificant results of the Levene's test, $F(1,88)=.678, p=$ .412 , indicated that the assumption of homogeneity of variances was met (Table 10). 
Table 10. Levene's test of equality of error variances

\begin{tabular}{llcl}
\hline$F$ & $d f 1$ & $d f 2$ & Sig. \\
\hline .678 & 1 & 88 & .412 \\
\hline
\end{tabular}

Based on the results displayed in Table 11, it can be claimed that the experimental group $(M=35.87, S E=.20)$ had a higher mean than the control group $(M=23.97, S E=.20)$ on the posttest of knowledge of grammatical structures after controlling for the possible effects of the pretest. It should be noted that these means were adjusted after controlling for the effects of the pretest.

Table 11. Descriptive statistics: Posttest knowledge of grammatical structures by groups on pretest

\begin{tabular}{lllll}
\hline \multirow{2}{*}{ Groups } & \multirow{2}{*}{ Mean } & Std. Error & \multicolumn{2}{l}{$95 \%$ Confidence Interval } \\
\cline { 3 - 5 } & & & Lower Bound & Upper Bound \\
\hline Experimental & $35.872^{\mathrm{a}}$ & .202 & 35.471 & 36.274 \\
Control & $23.972^{\mathrm{a}}$ & .202 & 23.570 & 24.374 \\
\hline
\end{tabular}

a. Covariates appearing in the model are evaluated at the following values: Pretest $=15.64$.

The ANCOVA results, $F(1,87)=1697.39, p=.000$, partial $\eta 2=.951$ representing a large effect size, indicated that the experimental significantly outperformed the control group on the posttest of knowledge on grammatical structures after removing the effect of the pretest. Thus the first null-hypothesis is rejected. It should be noted that the significant $F$-value associated with the pretest (i.e., $F=1180.80, p=.000$ ) indicated that the pretest was correctly assigned to be a covariate. In other words, the pretest had a significant rule in the ANCOVA model (Table 12).

Table 12. Tests of between-subjects effects: Posttest knowledge of grammatical structures by groups on pretest

\begin{tabular}{llcccccc}
\hline Source & $\begin{array}{l}\text { Type III } \\
\text { Squares }\end{array}$ & Sum of & & Mean Square & $F$ & Sig. & Partial Eta Squared \\
\hline Pretest & 2121.594 & 1 & 2121.594 & 1180.800 & .000 & .931 \\
Group & 3049.778 & 1 & 3049.778 & 1697.392 & .000 & .951 \\
Error & 156.317 & 87 & 1.797 & & & \\
Total & 85039.000 & 90 & & & & & \\
\hline
\end{tabular}

An independent samples $t$ test was run to compare the experimental and control groups' means on the speaking test in order to test second null hypothesis, which stated that comic strips have no significant effect on Iranian EFL learners' ability to use prepositions, simple future, and present continuous in speaking. Based on the results in Table 13 , it can be claimed that the experimental group $(M=15.42, S D=2.53)$ had a higher mean than the control group $(M=11.09, S D=3.40)$ on the speaking test. 
Table 113. Descriptive statistics: Speaking test by groups

\begin{tabular}{llllll}
\hline & Groups & $n$ & Mean & Std. Deviation & Std. Error Mean \\
\hline Speaking & Experimental & 45 & 15.42 & 2.538 & .378 \\
Test & Control & 45 & 11.09 & 3.402 & .507 \\
\hline
\end{tabular}

The results of the independent samples $t$ test, $t(88)=6.84, p=.000, r=.589$ representing a large effect size, indicated that the experimental significantly outperformed the control group on the speaking test. Thus, the second null hypothesis is rejected, too (Table 14).

Table 14. Independent samples $t$ test: Speaking test by groups

Levene's Test for Equality of Variances

$t$ test for Equality of Means

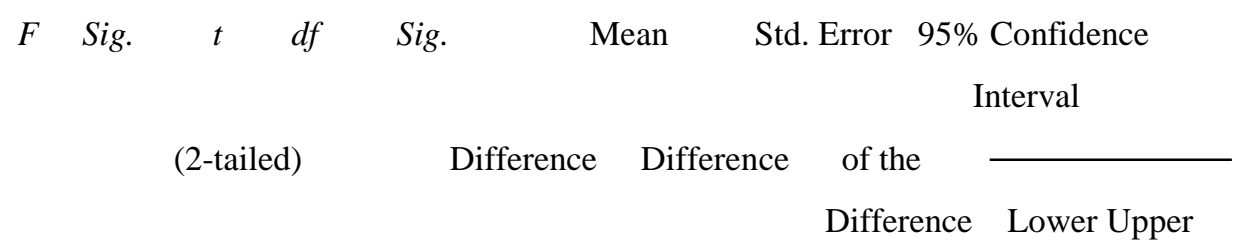

Equal

Variances

$\begin{array}{lllll}2.694 & .104 & 6.849 & 88 & .000\end{array}$

4.333

.633

3.0765 .591

Assumed

Equal

$\begin{array}{llllllll}\text { Variances } & 6.849 & 81.402 & .000 & 4.333 & .633 & 3.075 & 5.592\end{array}$

Not

Assumed

It should be noted that the assumption of homogeneity of variances was met. As shown in Table 14, the Levene's test was nonsignificant, $F=2.69, p=.104$. That is why the first row of the table, that is, Equal Variances Assumed is reported.

\section{Discussion}

The findings of the present study showed that the use of comic strips could improve both knowledge and performance in grammar among the participants in the experimental group compared to the control one. The improvement achieved in knowledge and performance of grammar could be associated with the clear descriptions of the stories in the comic strips, which helped to synchronize the visual and auditory learning of the grammatical structures during the treatment. Simply said, the use of comic strips was found useful in assisting the participants in understanding grammar because the comic strip and the dialog cooperated with each other, indicating that most expressions shown 
by the characters reflected the content of the dialog. Therefore, the participants could take advantage of guessing the use of the grammatical structure through visual exploration.

The results of this study showing the effectiveness of comic strips on grammar learning are in line with a number of other studies (Dougherty, 2002; Milton, 2008; Rule \& Schneider, 2009; Thomas, 2004). The results of this study indicate that comic strips can be an effective medium because not only they are unique, but also they are suitable to present grammar in a different way. This is supported by Purwanitasari (2019) who states that the use of comic strips is effective to increase L2 students' grammar achievement and to stimulate their motivation because comic strips are completed with interesting pictures and chronological order of the story, as it was so in the present study.

In the research carried out by Yaman and Yildiz (2008), similar results were reported. The researchers observed that L2 education is accompanied by the use of the visual materials to enhance L2 students' success. The findings of their research indicated that caricature could be used in Turkish grammar education. They finally concluded that the basic purpose of L2 grammar courses, which are based on teaching some abstract rules and concepts, is to give intuition on the L2 used by L2 students and to contribute to the development of their written and oral expression skills in this way. In this context, cartoons undertake an important function in the concretization of abstract rules and concepts of the L2 grammar.

Another study which corroborates the findings of the present study concerning the effectiveness of using comic strips was carried out by Wright (1990). He mentions that comic strips provide a sense of the context of the L2 and give a specific reference point or stimulus. The reason for this, he argues, may be the attractiveness of pictures for young L2 learners; the other may be that pictures have a more permanent effect on L2 learners. In fact, it is interesting for younger L2 learners to learn through picture presentation. Comic strips are visual instruction materials that can be used more effectively to develop and sustain motivation in producing positive attitudes towards English and to teach or reinforce L2 skills (Wright, 1990).

Although the present study did not measure motivation among the participants, the reason for the effectiveness of comic strips used in this study can be readily attributed to the motivation raised by visual presentation of grammar. Additionally, what happened during the teaching and learning process dealing with the use of comic strips was in line with Csabay (2006) and Yang (2017) who state that one of the strongest benefits of using comic strips to teach is the ability to motivate L2 students because comic strips bring a cheerful atmosphere into the class. If the classroom is enjoyable and attractive, the L2 students will learn preferably. Thus, an appropriate strategy combined with attractive instructional media is strongly recommended to create this condition. Spolsky (2000) proposed that a pleasant teaching style or strategy in the classroom can increase L2 students' motivation to learn.

Also, the results of the current study showed that the participants' grammatical performance, measured through speaking, was improved on account of using comic strips. This is compatible with what Pitoy (2012) argues in his study. He mentions that the stories of comic strips are be considered as a communicative source for L2 exposure. The exposure influences L2 students' way of thinking in understanding particular information during the teaching process. This study revealed that most participants could understand the grammatical structures well and could transfer them to their speaking. This can arguably indicate that the use of comic strips made the participants give full attention to the learning process. This affected their awareness and, thus, their subsequent performance. The positive effect of using comic strips on the participants' performance, as reflected in their speaking, is also supported by the results of the recent study conducted by Valdez (2016). She reported that using comics can be effective in improving functional grammar as used in speaking among Arab students.

As the final word to close this section, the results of the present study support the theory of contextualized teaching of grammar and emphasizes that isolated teaching of grammar has no beneficial results on writing development. This became apparent from the results from the speaking test regarding the grammar that the participants were exposed to in the treatment. In this way, the study holds the view that the traditional method of teaching grammar that includes rote learning has little benefit, if at all, to L2 students. Instead, the study proposes the use of visual teaching in the context of grammar instruction.

\section{Conclusion}

With regard to the importance placed on grammar, the purpose of the present study was to examine the possible effect of using comic strips in enhancing grammar knowledge and performance among Iranian EFL learners. The results were presented and discussed before. To recap, it was discovered that integrating grammar instruction with 
comic strips can lead to better learning of grammar on the part of L2 learners. Furthermore, it was revealed by the findings that the grammar taught through the application of comic strips can be produced by L2 students, which was channeled through speaking in this study. In fact, comic strips were both effective in improving grammar knowledge and performance among the participants in this study.

The first conclusion to be drawn from the findings should be about the reason for the effectiveness of comic strips, which may be hidden in the structure of comic strips. Comics are a unique combination of explaining an event and the art of drawing. Darvell (1997) stated that we never forget our childhood tales or movies that we watched many years ago. On the other hand, drawings and illustrations are doubtlessly effective teaching aids. One of the reasons for the effectiveness of comic strips may be the perfect match for these two components.

The findings of the present study have both practical and theoretical implications. The practical implications lie in the integration of a visual approach to teach grammar using a variety of visuals and visual imagery within grammar courses. In other words, the findings here support the view that comic strips have pedagogical value (Barbousas, 2009; Carifio \& Perla, 2009). In the light of this study, it was found that comic strips can be used to create mental images of sentence structures that help L2 students visually conceptualize the relationships between sentence parts and understand the functions of the parts in relation to the whole.

When it comes to the grammar in L2 students' speaking, comic strips can be useful tools, too. When used in interesting ways, as was the case in the present study, comic strips can motivate L2 students to learn grammar, which was directly used in their speaking in our study. Therefore, based on our findings, we can propose the reintroduction of using comic strips to teach sentence structure in the context of grammar instruction. Thus, it may be of significant value to introduce a visual approach in Iranian English pedagogy and for institutions to develop a curriculum for their L2 students that would include instruction of grammar using a visual approach and integrate it into their speaking curriculum. More specifically, L2 teachers should be made aware of the effectiveness of the use of comic strips in teaching grammar. Sharing research results such as those reported in this study can be useful in persuading L2 teachers to use such instruments as much as possible.

In line with the above, the findings of this study can have some practical implications for testing, too. In fact, the visual approach (i.e., comic strips) could be used not only for L2 teaching but also for testing L2 students' understanding and their grammar proficiency more efficiently. Comic strips could be used for testing knowledge and performance in all the skills of L2 learning. To give an example, L2 students may be required to explain the event which a certain set of comic strips are depicting. This can perfectly demonstrate their ability to perform their knowledge.

The results of this study hold theoretical implications as well. The current study contributes to the growing body of knowledge on the use of multimedia, especially the visual media, for teaching and learning grammar and making an impact on L2 learners' speaking development by contextualizing grammatical structures to be taught and learnt. Hence, this study can contribute to the idea of teaching in context by an evidence-supported emphasis on the effectiveness of using comic strips as the context of grammar knowledge and production. Though to a lesser extent, this study can theoretically support the idea that comic strips can foster motivation learning and producing grammar. We, however, admit that the participants' level of motivation was not gauged in this study. Still, there is a strong case for an argument for the role of motivation in learning grammar, in particular, and English as an L2, in general.

Obviously, almost no research is exhaustive and further research is necessary to verify and validate the results of any research. The participants of the current study were young, preintermediate L2 learners; replications should be made using participants of other age groups and proficiency levels. Because L2 learning is a culture-bound phenomenon (Dehmardeh \& Wray, 2011), the design used in this study could also be applied using learners of other languages. As the last word, we hope this study can act as a springboard to promote and encourage further investigation concerning using comic strips in L2 teaching/learning.

\section{References}

Abbasian Boroujeni, F. (2012). Investigating controversies in teaching grammar: A case for the Iranian high school students. Theory and Practice in Language Studies, 2(8), 1570-1575. doi:10.4304/tpls.2.8.1570-157 
Akkaya, A. (2013). A different activity in grammar learning in Turkish course: Educational comic strips. International Journal of Academic Research, 5(5), 118-123. doi: 10.7813/2075-4124.2013/55/B.18

Arast, O., \& Gorjian, B. (2016). The effect of listening to comic strip stories on incidental vocabulary learning among Iranian EFL learners. Journal of Applied Linguistics and Language Learning, 2(1), 17. doi:10.5923/j.jall1.20160201.01

Bachman, L. (1990). Fundamental considerations in language testing. Oxford University Press.

Barbousas, J. (2009). The visual education movement: The emergence of visual technology in education. The International Journal of Learning, 16(10), 169-180. doi: https://doi.org/10.18848/14479494/CGP/v16i10/46679

Bringelson, C. (2010). Comics in the educational sphere. School Library Monthly, 26(10), 23-23.

Carifio, J., \& Perla, R. J. (2009). A critique of the theoretical and empirical literature of the use of diagrams, graphs, and other visual aids in the learning of scientific-technical content from expository texts and instruction. Interchange, 40(4), 403-436. https://doi.org/10.1007/s10780-009-9102-7

Chaikovska, O. (2018). Benefits of teaching ESL through comic strips. Web of Scholar, 4(1), 8-11.

Crivos, M. B., \& Luchini, P. L. (2012). A pedagogical proposal for teaching grammar using consciousness-raising tasks. MJAL, 4(3), 141-153.

Csabay, N. (2006). Using comic strips in language classes. English Teaching Forum, 44(1), 24-26. https://americanenglish.state.gov/files/ae/resource_files/06-44-1-f.pdf

Darvell, L. (1997). The importance of story. Primary Educator, 3(1), 8-9.

Dehmardeh, M., \& Wray, D. (2011). Culture and English language teaching in Iran. The Iranian EFL Journal, $7(5), 264-281$

Dougherty, B. K. (2002). Comic relief: Using political cartoons in the classroom. International Studies Perspectives, 3(3), 258-270. https://doi.org/10.1111/1528-3577.00095

Foulsham, T., Wybrow, D., \& Cohn, N. (2016). Reading without words: Eye movements in the comprehension of comic strips. Applied Cognitive Psychology, 30(4), 566-579. doi: 10.1002/acp.3229

Hadzigeorgiou, Y., \& Stefanich, G. (2000). Imagination in science education. Contemporary Education, 71(4), 23-28. https://www.proquest.com/openview/5468e72cfeeecefa8ca1d81c08ad83c3/1?pqorigsite $=$ gscholar $\& \mathrm{cbl}=1816594$

Hatch, E., \& Lazaraton, A. (1991). The research manual. Design and statistics for applied linguistics. New York: Newbury House Publishers.

Hayman, P., Greg, H., \& Pratt, T. (2005). What are comics? A reader in philosophy of the arts. Upper Saddle River, NJ: Pearson Education, Inc.

Hoven, D. (1999). A model for listening and viewing comprehension in multimedia environments. Language Learning and Technology, 3(1), 88-103. https://www.learntechlib.org/p/90919/

Kabapinar, F. (2005). Effectiveness of teaching via concept cartoons from the point of view of constructivist approach. Educational Sciences: Theory \& Practice, 5(1), 135-146.

Kilickaya, F., \& Krajka, J. (2012). Can the use of Web-based comic strip creation tool facilitate EFL learners' grammar and sentence writing? British Journal of Educational Technology, 43(6), 161-178. doi: 10.1111/j.1467-8535.2012.01298.x

Kost, C., Foss, P., \& Lenzini, J. (1999). Textual and pictorial gloss: Effectiveness on incidental vocabulary growth when reading in a foreign language. Foreign Language Annals, 32(1), 89-113. doi: 10.1111/j.19449720.1999.tb02378.x 
Kusumawati, E., \& Khairuddin, K. (2017). Instructions, comic strips and ESP reading comprehension. Seminar Nasional Sistem $\quad$ Informasi, $\quad 1(1), \quad 141-151$. https://jurnalfti.unmer.ac.id/index.php/senasif/article/view/34

Lin, H. C. (2010). A case study: An ESL teacher's beliefs and classroom practices in grammar instruction. Unpublished doctoral dissertation, Kent State University, U.S.

Liu, J. (2004). Effects of comic strips on L2 learners' reading comprehension. TESOL Quarterly, 38(2), $225-243$. https://doi.org/10.2307/3588379

Liu, M., Moore, Z., Graham, L., \& Lee, S. (2002). A look at the research on computer-based technology use in second language learning: A review of the literature from 1990-2000. Journal of Research on Technology in Education, 34(3), 250-273. https://doi.org/10.1080/15391523.2002.10782348

Mayer, R. E., \& Moreno, R. (2002). Aids to computer-based multimedia learning. Learning and Instruction, 12(1), 107-119. https://doi.org/10.1016/S0959-4752(01)00018-4

McVicker, C. J. (2007). Comic strips as a text structure for learning to read. The Reading Teacher, 61(1), 85-88. doi: 10.1598/RT.61.1.9

Megawati, F., \& Anugerahwati, M. (2012). Comic strips: a study on the teaching of writing narrative texts to Indonesian EFL $\quad$ students. TEFLIN $\quad$ Journal, 23(2), $183-205 . \quad$ doi: http://dx.doi.org/10.15639/teflinjournal.v23i2/183-205

Merc, A., \& Kampusu, Y. (2013). The effect of comic strips on EFL reading comprehension. International Journal on New Trends in Education and Their Implications, 4(1), 54-64.

Milton, J. (2008). Vocabulary uptake from informal learning tasks. Language Learning Journal, 36(2), $227-237$. doi: 10.1080/09571730802390742

Moore, D. S., \& McCabe, G. P. (2006). Introduction to the practice of statistics. Den Haag: Academic Service.

Nassaji, H. (2003). Higher-level and lower-level text processing skills in advanced ESL reading comprehension. The Modern Language Journal, 87(2), 261-276. https://doi.org/10.1111/1540-4781.00189

Persha, A. J., \& Nawvi, K. R. (2004). Visual stimulation activities for infants and toddlers-A guide to parents and caregivers. Secunderadad, India: National Institute for the Mentally Handicapped, SreeRamana Process Pvt, Ltd.

Pitoy, S. P. (2012). Information and language for effective communication. TEFLIN Journal, 23(1), 91-114. doi: http://dx.doi.org/10.15639/teflinjournal.v23i1/91-114

Purwanitasari, L. (2019). Using comic strips to improve the ability of students of SMP Negeri 2 Malang in writing recount text. Unpublished master's thesis, State University of Malang.

Rinvolucri, M., \& Davis, P. (1995). More grammar games: Cognitive, affective, and movement activities for EFL students. Cambridge: Cambridge University Press.

Rota, G., \& Izquierdo, J. (2003). Comics as a tool for teaching biotechnology in primary schools. Electronic Journal of Biotechnology, 6(2), 85-89. doi: 10.2225/vol6-issue2-fulltext-i02

Rule, A. C., \& Schneider, J. S. (2009). Creating, evaluating, and improving humorous cartoons related to design principles for gifted education programs. Cedar Falls, Iowa: Department of Curriculum and Instruction University of Northern Iowa.

Spolsky, B. (2000). Anniversary article. Language motivation revisited. Applied Linguistics, 21(2), $157-169$. https://doi.org/10.1093/applin/21.2.157

Sun, Y., \& Dong, Q. (2004). An experiment on supporting children's English vocabulary learning in multimedia context. Computer Assisted Language Learning, 17(2), 131-147. https://doi.org/10.1080/0958822042000334217 
Thomas, S. J. (2004). Teaching America's GAPE (or any other period) with political cartoons: A systematic approach to primary source analysis. The History Teacher, 37(4), 425-446. https://doi.org/10.2307/1555548

Turkmen, H. (2008). Turkish primary students' perceptions about scientists and what factors affecting the image of the scientists. Eurasia Journal of Mathematics, Science, and Technology Education, 4(1), 55-61. doi: $10.12973 /$ ejmste/75306

Valdez, S. F. (2016). The effectiveness of interactive comic strips on teaching functional grammar to college freshmen. International Journal of English Language, Literature, and Humanities, 4(2), 39-52. https://ijellh.com/OJS/index.php/OJS/article/view/1120

van Patten, B., \& Lee, J. F. (2003). Making communicative language teaching happen (2 ${ }^{\text {nd }}$ ed.). New York: McGraw-Hill.

Williams, N. (1995). The comic book as course book: Why and how. Annual Meeting of the Teachers of English to Speakers of Other Language, 1(2), 1-27. https://files.eric.ed.gov/fulltext/ED390277.pdf

Wolschke-Bulmahn, J., \& Groning, G. (1994). Children's comics: An Opportunity for Education to Know and to Care for Nature? Children's Environments, 11(3), 232-242. https://www.jstor.org/stable/41515265

Wright, A. (1990). Pictures for language learning. Cambridge: Cambridge University Press.

$\mathrm{Wu}, \mathrm{C} . \mathrm{H}$. (2007). Spoken grammaticality and EFL teacher candidates: measuring the effects of an explicit grammar teaching method on the oral grammatical performance of teacher candidates. Unpublished doctoral dissertation, The Ohio State University, U.S.

Yaman, H., \& Yildiz, C. (2008). Concept mapping in Turkish grammar instruction: A quantitative and qualitative research study. World Applied Sciences Journal, 5(3), 367-377. http://www.idosi.org/wasj/wasj5(3)/17.pdf

Yang, G. (2017). Comics in education. Online version of the final project proposal for Masters of Education degree of the author at California State University at Hayward 2003. 


\section{Appendix A: Pretest}

\section{Directions: Complete the following conversation.}

A: Hello jack. When will you give my money back

B: Hello Fred. I................ (pay) you next month.

A: Thank you. ............... (pay) it to my account or in cash?

B: I think I ................ (not have) cash. I.............. (give) you the money through check.

\section{Appendix B: Posttest \\ Directions: Complete the following conversation.}

A: Hi. When do you think you will finish your project?

B: Hello teacher. I................ (do) it next week.

A: Thank you. ............... (deliver) it by email or in person?

B: I think I ............... (not send) it by email. I.............. (deliver) it by myself to your office.

A: I will be waiting for you.

\section{Appendix C: Speaking Interview Questions}

1. (The rater puts the pen on the desk) Where is the pen?

2. Where is the book?

3. Now, where is my cell phone?

4. Tell me where the glass is.

5. Where is the marker now?

6. (The rater walks in the class) what am I doing?

7. What are you doing?

8. What is your brother doing now?

9. Tell me what your father is doing now?

10. What am I doing right now?

11. (The rater shows a ticket to Shiraz) where will I go tomorrow?

12. Where will you go after the class?

13. When will you finish this semester? 